\title{
Barcoding and interspecific relationships of Macaronesian Weevils (Coleoptera: Curculionoidea)
}

With 2 figures, 1 table and an electronic supplement

Peter E. Stüben ${ }^{1}$, André Schütte ${ }^{2}$ and Jonas J. Astrin ${ }^{2}$

${ }^{1}$ CURCULIO-Institute, Hauweg 62, 41066 Mönchengladbach, Germany. - p.stueben@t-online.de
${ }^{2}$ ZFMK: Zoologisches Forschungsmuseum Alexander Koenig, Adenauerallee 160, 53113 Bonn, Germany
Published on 2021-06-30

DOI: 10.21248/contrib.entomol.71.1.127-135

\section{Abstract}

In an integrative taxonomic approach, this study presents mitochondrial CO1 barcodes for 468 of the 735 so far described Lauri-Macaronesian weevil (Curculionoidea) species and subspecies in $\mathbf{1 3 8 8}$ samples. A Bayesian tree (electronic supplement) provides insights into within-species relationships, without aiming at phylogenetic accuracy above genus level. With the exception of a few discussed cases, the present dataset of DNA barcodes allows a reliable re-identification and remarkable differentiation of species and will accelerate the discovery of new weevil species from the Canary, Madeira and Azores archipelagos. Only in a single case, the similar species Rhinoncus castor and $R$. bruchoides (Ceutorhynchinae) from Madeira, did the molecular (re)identification reveal an unresolvable contradiction with our morphological species identification. In many cases, morphological determinations were bolstered by comparisons with the type material. Sequenced specimens were mounted and deposited in a reference collection for later re-determinations.

\section{Key words}

Integrative taxonomy, CO1, morphology, Bayesian tree, cryptic species, young species splits, species complexes, Canary Islands, Madeira archipelago, Savage Islands, Azores

\section{Zusammenfassung}

In dieser integrativ-taxonomischen Studie werden für 468 der 735 bisher beschriebenen lauri-makaronesischen Arten und Unterarten der Rüsselkäfer (Curculionoidea) mitochondriale CO1-Barcodes in 1388 Proben vorgelegt. Ein Bayes'scher Baum (elektronisches Supplement) gibt Einblicke in die Beziehungen innerhalb der Arten und Unterarten, ohne ein phylogenetisches Gesamtbild oberhalb der Gattungsebene anzustreben. Mit Ausnahme einiger weniger diskutierter Fälle erlaubt der vorliegende Datensatz von DNA-Barcodes eine zuverlässige Re-Identifizierung und bemerkenswerte Differenzierung von Arten und wird die Entdeckung und Beschreibung neuer Rüsselkäfer-Arten - sowie deren (Re-) Synonymisierung - von den Kanaren, Madeira, und den Azoren beschleunigen. Nur in einem einzigen Fall, bei den eingewanderten, verwandten Arten Rhinoncus castor und R. bruchoides (Ceutorhynchinae) aus Madeira, ergab die molekulare (Re-)Identifizierung einen unauflösbaren Widerspruch zu unserer morphologischen Artbestimmung. In den meisten Fällen wurden die morphologischen Bestimmungen zuvor durch Vergleiche mit dem Typenmaterial untermauert und sequenzierte Exemplare wurden in einer Referenzsammlung für spätere Nachbestimmungen hinterlegt. 


\section{Introduction}

The Macaronesian Islands (according to ancient Greek geographical literature ' $\mu \alpha \kappa a ́ \rho \omega \nu v \tilde{\sigma} \sigma o เ$ makáron nẽsoi': "islands of the fortunate") include the archipelagos of volcanic origin located in the eastern Central Atlantic:

- The Azores (Portugal, 36 $43^{\prime}-39^{\circ} 56^{\prime} \mathrm{N}$ and $24^{\circ} 46^{\prime}$ $\left.31^{\circ} 16^{\prime} \mathrm{W}\right)$, spread over a length of $600 \mathrm{~km}$, with the 9 islands of Santa Maria and São Miguel in the southeast, the central islands Terceira, São Jorge, Pico, Faial and Graciosa as well as Flores and Corvo far in the northwest. They are part of the Mid-Atlantic Ridge and lie on the plate boundary between the European plate and the North American plate around $1400 \mathrm{~km}$ west of mainland Europe. The mountain Pico $(2351 \mathrm{~m})$ is the highest volcano on the island of Pico of the same name.

- The Madeira archipelago (Portugal, $32^{\circ} 45^{\prime} \mathrm{N}, 17^{\circ} 0^{\prime} \mathrm{W}$ ) about $1000 \mathrm{~km}$ southwest of the Portuguese capital Lisbon, with the main island Madeira and the small island of Porto Santo, $42 \mathrm{~km}$ to the northeast, as well as the offshore archipelago of Ilhas Desertas (Ilhéu Chão, Deserta Grande and Bugio) to the southeast. Madeira lies on the African Plate. The highest mountain is Pico Ruivo at $1862 \mathrm{~m}$.

- The Ilhas Selvagens or 'Savage Islands' (Portugal, $30^{\circ} 9^{\prime} \mathrm{N}, 15^{\circ} 52^{\prime} \mathrm{W}$ ) with the less than 3 square kilometres largest island Selvagem Grande and the tiny islands Selvagem Pequena $\left(0.30 \mathrm{~km}^{2}\right)$ and Fora $\left(0.08 \mathrm{~km}^{2}\right)$ located about $15 \mathrm{~km}$ to the southwest, as well as 15 other, partly very small islets. These islands, which have been strictly protected since 1971, are located $280 \mathrm{~km}$ to the south of Madeira and $165 \mathrm{~km}$ to the north of Tenerife. The highest peak is the Pico da Atalaia on Selvagem Grande at $163 \mathrm{~m}$.

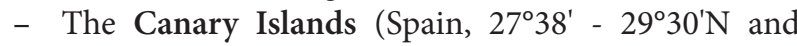
$13^{\circ} 22^{\prime}-18^{\circ} 11^{\prime} \mathrm{W}$ ) with the 7 islands of Lanzarote and Fuerteventura (also called 'Purpuraria') in the east, the central island of Gran Canaria and the western islands of Tenerife, La Gomera, La Palma and El Hierro. The east-west extension is about $500 \mathrm{~km}$, and the shortest distance to the African mainland is just $100 \mathrm{~km}$. To the north of Lanzarote is the small inhabited island of Graciosa, and there are 5 other uninhabited islands as well as a few tiny rocky islets. The highest point is the Pico del Teide on Tenerife (3715 m).

The term (Great) Macaronesia, which goes back to the botanist Philip Barker Webb (1793-1854), includes also the independent islands of Cape Verde, parts of the Atlantic coast of Morocco and the extreme southwestern tip of the Iberian Peninsula. In this study, however, we restrict ourselves mainly to Lauri-Macaronesia, a floral region that is characterized by the occurrence of (recent) laurel forests ('laurisilva') on the archipelagos of the Azores, Madeira and Canaries (Fig. 1).

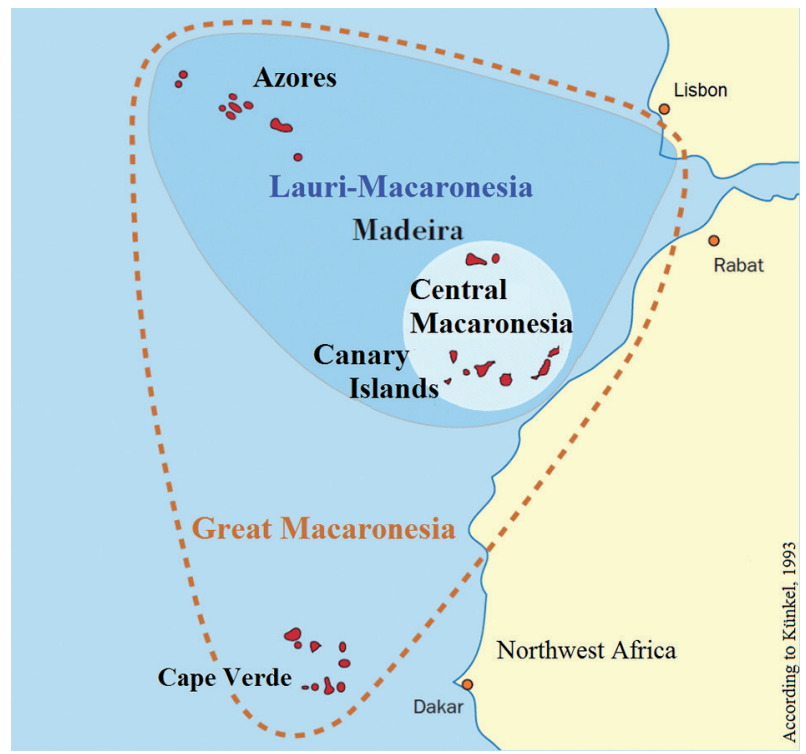

Fig. 1: Lauri-Macaronesia (revised according to Künkel, 1993).

\section{Aims and perspectives}

Integrative Taxonomy as we understand and implement it makes, inter alia, use of both approaches: the molecular and the morphological methods. This is not only a question of comparison and alignment of two different methods. It is important to keep history of science in mind: Whenever we generate DNA barcodes from known species, we have to be certain that we connect to the binomial names from the taxonomic literature. This may sound like an insignificant detail, but it is not: It is of paramount importance, as there has to be a permanently traceable link between 'genotype and phenotype' if we do not want to turn away from the nearly three-hundredyear-old history of entomology (since Carl Linnaeus) and from all the achievements accomplished therein so far. Who better than the - primarily - morphologically working taxonomist could place the correct species names on DNA barcodes, pass on valid names that are linked to types deposited at museums and could tie in with our great entomological past?

Therefore, in almost all cases, the explicit alignment with the existing Macaronesian type material was in the focus of this work (secondarly, this also includes obtaining material from the type localities). The photographic documentation (habitus \& aedeagus) as well as exact information on the whereabouts of the types in the numerous museums of Europe can be found for the most part in "The Macaronesian Islands - an Encyclopedia of Curculionoidea” (STÜBEN 2016a and following years) and soon in Stüben (in press). The identification of the underlying material was primarily done by the first author, who also recurred to the kind help of his colleague A. Machado (Tenerife) for the identification of the Laparocerini. Even more important, however, is another step: the subsequent accessibility of the mate- 
rial for validation purposes of the sequenced specimens which can be loaned from the 'Zoologisches Forschungsmuseum Alexander Koenig' (ZFMK, Germany: Bonn), the 'Museum of Natural History Basel' (Switzerland) and the 'Curculio Institute' (CURCI, Germany: Mönchengladbach) at any time. In this way, the full molecular-morphological circle is closed in integrative taxonomy.

Apart from this rather retrospective and more methodological view, and based on the now standardised sequence of the CO1 barcoding gene (HEBERT et al. $2003 \mathrm{~b}$ ) the identification of species will always be easier for us (see electronic supplement, Fig. 2). This study, with its Bayesian $50 \%$ majority rule consensus tree built from mitochondrial CO1 gene sequence, does never promise deeper phylogenetic insight above the genus level. It cannot and is not intended to! This is already clear from the fact that we obtain in a few cases a paraphyletic picture of 'isolated' subfamilies, genera and groups, which does not suggest a deeper monophyly. We could only make assumptions in this direction by including more genes, above all nuclear genes, or genomes. Notwithstanding, both provide the 'light at the end of the tunnel', carried by the hope that we will move towards an increasingly clear and precise classification and identification of species as well as of their closest relatives.

\section{Material and methods}

\section{Taxon sampling}

Two dozen trips between 1998/99 and 2020 have taken the first author to all the islands of the Canaries between two weeks and two to three months. All islands were visited several times. A total of 11 excursions took place on the Madeira archipelago in this time, including four trips to Porto Santo, two excursions to the Ilhas Desertas and a three-week expedition to the Ilhas Selvagens, located in the middle of the Atlantic Ocean between Madeira and the Canary Islands. The first author spent 4 to 6 weeks on seven of the nine islands of the Azores in 2003 and 2018. He was accompanied a few times by the co-authors. The results of the numerous research trips was published in the Snudebiller editions in nine individual catalogues to the 22 Macaronesian islands (STÜBEN 2011, 2014, 2016b, 2017, 2018a/b; SтÜвеN \& BeHne 2013, 2015, SтÜвеN \& Borges 2019). $98 \%$ of this material comes from these research trips during which the collected weevils were directly transferred into 96-99\% ethyl alcohol. All other collections come from various colleagues, in particular P.A.V. Borges (Terceira) who provided us with trap material from the Azores. After DNA extraction, the specimens previously separated between prothorax and mesothorax were reassembled and - where necessary the aedeagus, already cleaned of all soft tissue parts, was removed, prepared, labelled with the GenBank accession number for the DNA barcode, and finally transferred to the permanent reference collection (see above).

The Palaearctic Catalogues (in the last printed version) under the editorship of LöBL \& SMETANA (2011, 2013), on which the first author still worked on the compilation of the Macaronesian Cryptorhynchinae (STÜBEN 2018c), served for a first taxonomic classification of the weevils. Anthribidae, Scolytidae and Platypodidae remain unconsidered in this study (especially as the position of the Scolytidae has not been conclusively clarified; HundsDÖRFER et al. 2009).

468 of the 735 sub-/species (including 231 Laparocerini and 127 Cryptorhynchinae) in $\mathbf{1 2 3}$ genera from the 22 Macaronesian islands in $\mathbf{1 3 8 8}$ samples from different localities and islands could be DNA barcoded and integrated into a Bayesian $50 \%$ majority rule consensus tree (see electronic supplement, Fig. 2). The total number also includes two dozen $\mathrm{CO} 1$ sequences by some colleagues from the Canary Islands, obtained from GenBank or provided directly to us (GARCía et al. 2019, MACHADO 2020, GARCía \& López 2020). It should not go unmentioned at this point that we have only sequenced 51 species of the mega-genus Laparocerus, which now includes 222 sub-/species (at the end of 2020). We assume that this task will be done by the Laparocerini specialist A. Machado in close cooperation with Bent Emerson and his team (Instituto de Productos Naturales y Agrobiología (IPNA), Tenerife), who have the relevant DNA material and already performed this work for some other mitochondrial and nuclear genes (in litt. MACHADO).

Among the species we sequenced, there are 345 endemic sub-/species that can only be found on the Macaronesian Islands and further 60 native species occurring mainly in the Mediterranean region, but also throughout the Western Palearctic. All other species concern introduced or invasive species from all parts of the world. Of course, future work will focus on closing the gap by focusing on the species not barcoded yet, a task to be approached together with our colleagues from the Canaries, Madeira, and the Azores.

\section{DNA isolation, amplification and sequencing}

Genomic DNA was extracted from either legs or nondestructively from whole specimens using a BioSprint96 magnetic bead extractor and corresponding kits (Qiagen: Hilden, Germany), following the manufacturer's protocol. Individual samples were processed using silica membrane-based spin columns.

We amplified $658 \mathrm{bp}$ from the 5'-end of the COI (cytochrome $c$ oxidase subunit I) gene with degenerate primers (see Tab. 1) using standard PCR conditions in reaction volumes of $20 \mu \mathrm{l}$, including $2.5 \mu \mathrm{l}$ of undiluted DNA template, and using the 'Multiplex PCR Master Mix' (Qiagen). Thermal cycling was performed on Gene- 
Amp PCR System 2700 instruments (Life Technologies, Carlsbad, USA) as follows: hot start Taq activation: $15 \mathrm{~min}$ at $95^{\circ} \mathrm{C}$; first cycle set, 'touch down' (15 repeats): $35 \mathrm{~s}$ denaturation at $94^{\circ} \mathrm{C}, 90 \mathrm{~s}$ annealing at $55^{\circ} \mathrm{C}\left(-1^{\circ} \mathrm{C} /\right.$ cycle) and $90 \mathrm{~s}$ extension at $72^{\circ} \mathrm{C}$. Second cycle set $(25$ repeats): $35 \mathrm{~s}$ denaturation at $94^{\circ} \mathrm{C}, 90 \mathrm{~s}$ annealing at $40^{\circ} \mathrm{C}$ and $90 \mathrm{~s}$ extension at $72^{\circ} \mathrm{C}$; final elongation $10 \mathrm{~min}$ at $72^{\circ} \mathrm{C}$. Amplicons were purified with the ExoSAP-IT kit (USB Corporation, Cleveland, Ohio) and sequenced bidirectionnally using the PCR primers at Macrogen Europe's commercial Sanger sequencing service (Amsterdam, NL). The 1388 sequences were assembled, inspected and aligned using Geneious vers. R7 (Biomatters, Auckland, New Zealand).

\section{Belidae - still pose some puzzles}

The Belidae belong to the morphologically more basal weevil families with straight, non-geniculate antennae. Most Belidae live as larvae inside diseased or dead branches of woody plants.

As the molecular phylogram shows, the two Aglycyderes species are embedded in two clearly distinguishable clades on the Canary Islands. The p-distance of the mitochondrial COI gene is $11.3 \%$ - $11.8 \%$ (STÜBEN et al. 2015). So far only Aglycyderes setifer WESTwOoD, 1864, was known from the Canary Islands. It was only some years ago that molecular analysis opened up a view of the second, hitherto little known species Aglycyderes tavakiliani, described

Tab. 1: Primers used in polymerase chain reaction and sequencing in this study. Combination JJ2 was used only in cases where combination JJ failed. Primer loci correspond to the priming sites described by Folmer et al. (1994), the fragment typically used in animal DNA barcoding (HeBert et al. 2003a, b).

\begin{tabular}{|ll|l|}
\hline Primer name & \multicolumn{1}{c|}{ Sequence } & \multicolumn{1}{c|}{ Publication } \\
\hline LCO1490-JJ & 5'-CHACWAAYCATAAAGATATYGG & Astrin \& Stüben 2008 \\
HCO2198-JJ & 5'-AWACTTCVGGRTGVCCAAARAATCA & Astrin \& Stüben 2008 \\
\hline LCO1490-JJ2 & 5'-CHACWAAYCAYAARGAYATYGG & Astrin et al. 2016 \\
HCO2198-JJ2 & 5'-ANACTTCNGGRTGNCCAAARAATCA & Astrin et al. 2016 \\
\hline
\end{tabular}

Bayesian trees were inferred with MrBayes v. 3.2.7 (Ronquist et al. 2012). Parameters were unlinked between the 3 rd versus 1 st plus 2 nd codon positions. We ran two independent replicates (4 chains each) for 30 million generations per analysis. Every 1000th tree was sampled. Negative log-likelihood score stabilization was determined in a separate visualization. Accordingly, we retained 59,742 trees, which were used for building a 50\%-majority rule consensus tree with posterior probabilities(see electronic supplement, Fig. 2).

The labelling of the taxa in the phylogenetic tree comprises species name, collecting number, GenBank number (where also geo-coordinates for the samples can be found), and collecting locality.

\section{Results and discussion}

Only those species are briefly presented here in which the discrepancy between external appearance and molecular results raises questions and where further investigation is recommended. Nomenclatural changes, e.g. synonymisations and resynonymisations as well as the description of new species/subspecies and new genera/subgenera will soon be presented in a comprehensive book publication on the 'Weevils of Macaronesia - Canary Islands, Madeira, Azores' by the first author (in press). In all cases, use the electronic supplement (Fig. 2) for comparison. by Menier from Morocco in 1974, which was first beaten by the first author in the south of Tenerife from succulent, dried plants, on La Palma from dead Ficus branches and on La Gomera from completely dried plant remains of Kleinia neriifolia (Senecio kleinia). On Fuerteventura, we could only sift one specimen (2750-PST) from the dustdry detritus of Cynara cardunculus, and this specimen is puzzling in several ways. After molecular sequencing of the mitochondrial COI gene, the species appears in the same clade as Aglycyderes tavakiliani Menier, 1974, but does not seem to be the same, as the uncorrected distance (p-distance) of the COI gene to the other A. tavakiliani amounts to almost $6 \%$. So this specimen could very well represent a new species or subspecies, which would then have to be described, or alternatively it could belong to the original A.tavakiliani described by Menier from Morocco. See also the morphological study by MARVALDI et al. (2006) on the phylogenetic relationships among the genera of the subfamily Oxycoryninae and other belids (Curculionoidea).

\section{Auletobius anceps (Attelabidae) - a species complex?}

The species is highly polymorphic on the Canary Islands. Based on the lectotype in the British Museum (coll. Wollaston), the species is one of the smaller representatives of the genus $(1.5-2.8 \mathrm{~mm})$, the antennal club is darkened and thus clearly separated from the rest of the yellow antenna, the onychium is short and at most as long as first tarsomere and almost always the sutural strip is conspicuously black or dark brown. However, there are specimens on Tenerife and Gran Canaria that 
deviate considerably from this. They are much larger (up to $4 \mathrm{~mm}$ ), have entirely yellow antennae and a darkened sutural stripe on the elytra is sometimes missing. This diversity or variability, on the other hand, is not clearly comprehensible in the molecular phylogram, which leads to the assumption that this could be a very recent lineage split.

On La Palma, on the other hand, there is another species besides A. anceps and A.cylindricollis, which the first author was able to record for the first time on Mount Tagoja (La Palma) and which so far can only be separated molecularly - albeit by high edge lengths in the CO1 phylogram (listed under the sequencing number “1699-PST”). Its morphological differential diagnosis causes great difficulties, and in any case further sequence analyses of specimens from many other localities will be needed in the future.

\section{Hemitrichapion wagneri wagneri vs. H. w. gomerense - just a colour play?}

Hemitrichapion wagneri gomerense STÜBEN \& BEHNE, 2010, is without exception a red-copper metallic species on La Gomera (type locality) and El Hierro, while the nominotypic taxon from the Iberian Peninsula appears bluish green (type locality is Cascais, Portugal). The two subspecies living on various Lotus species cannot actually be confused with each other and are certainly not conspecific from a morphological point of view! However on Tenerife there even seems to be two species/ subspecies: H. wagneri gomerense and another coppercoloured, cryptic (sub)species, which clusters together with $H$. wagneri wagneri (FLACH, 2006) from Portugal (Estremadura) and Spain (Andalucía) in the tree. If the clear clade formation can be confirmed, there would be no objection to a (sub)species splitting, but in such cases one should not forego the molecular investigation of many more populations from the named islands in order to exclude polyphyly and/or paraphyly; otherwise - and in what we consider to be a very unlikely case - the two (sub)species would only be colour variants of the same species.

\section{Taeniapion cf. diverserostratum - new cryptic species} emerge

Besides the detailed presentation of the resynonymisation of Taeniapion diverserostratum (in 'Weevils of Macaronesia', STÜвEN in press), we seem to be dealing with another cryptic Taeniapion species on La Gomera. All the specimens we sequenced from the western islands using the CO1 gene (El Hierro, La Gomera, La Palma, Gran Canaria) fall into a clade that is clearly separated from the other known Macaronesian Taeniapion species. It is notable that the specimens from La Gomera and Tenerife form a coherent subclade with p-distances between $2.8 \%$ and $3.8 \%$. The morphological differential diagnosis still causes difficulties, but the molecular discoveries pose a new question: Are we dealing with the reproductive isolation of another Taeniapion species on two neighbouring islands, namely La Gomera and Tenerife?

\section{Cionus griseus versus $C$. variegatus - or just a very variable species?}

Both species occur on Tenerife (apparently only at different altitudes, unclear from the present data). The molecular analysis of the CO1 gene is clear: Two completely differently coloured Cionus species on two different endemic Scrophulariaceae - namely Scrophularia glabrata and Scrophularia smithii langeana - can be distinguished morphologically from their markings but not molecularly (p-distance $<0.9 \%$ )! Therefore, the initial suspicion is that Cionus griseus on Tenerife could be a younger synonym of Cionus variegatus. So the first author searched for more specimens on the other Canary Islands and found C. variegatus on La Gomera on the introduced Scrophulariaceae Verbascum virgatum; a first indication that there is not necessarily a strict host plant link on every island. Molecularly, the small p-distances of these specimens in comparison to the specimens on Tenerife do not speak in favour of a species distinct from C. griseus $(<1.7 \%)$. However, clearly different from this - in a sister clade are the specimens of C. griseus/variegatus on La Palma (p-distances: $3.8 \%-4.4 \%$ ), and this shows the full extent of the morphological confusion: due to the colour pattern it is difficult to tell which of the two species we are dealing with (Fig. 3). On the other hand, it cannot be conclusively clarified at the mitochondrial level, whether it is actually a case of introgression after hybridization on La Palma and Tenerife. This in turn would make a claim for a very young species separation. However, this requires further extensive molecular nuclear gene studies. Interim conclusion: The whole matter may be much more complex and difficult than the different colour patterns (of colour morphs?) in exclusively morphological studies suggest (Kostal \& CALDARA 2019).

\section{Lixus brevirostris - molecular discovery of new species features}

The 'Lista/2009' mentions Lixus brevirostris only for the islands of La Palma, Tenerife, Gran Canaria and Fuerteventura. From the latter island, the first author is currently describing a new species (Stüben in prep.). He reported also the L. brevirostris for La Gomera (STÜBEN 2011) and later also for El Hierro (STÜBEN 2018a). The species is ubiquitous and not rare on Chenopodiaceae. However, the analysis of the mitochondrial CO1 gene leaves no doubt that there are 2 or 3 (sub)species! On the one hand, there are two main clades (p-distance $=6.5 \%$ - $7 \%$ ) including the specimens from Gran Canaria and Tenerife, and on the other hand those from La Gomera and La Palma/El Hierro, with populations from the latter two islands forming another subclade in the mitochon- 

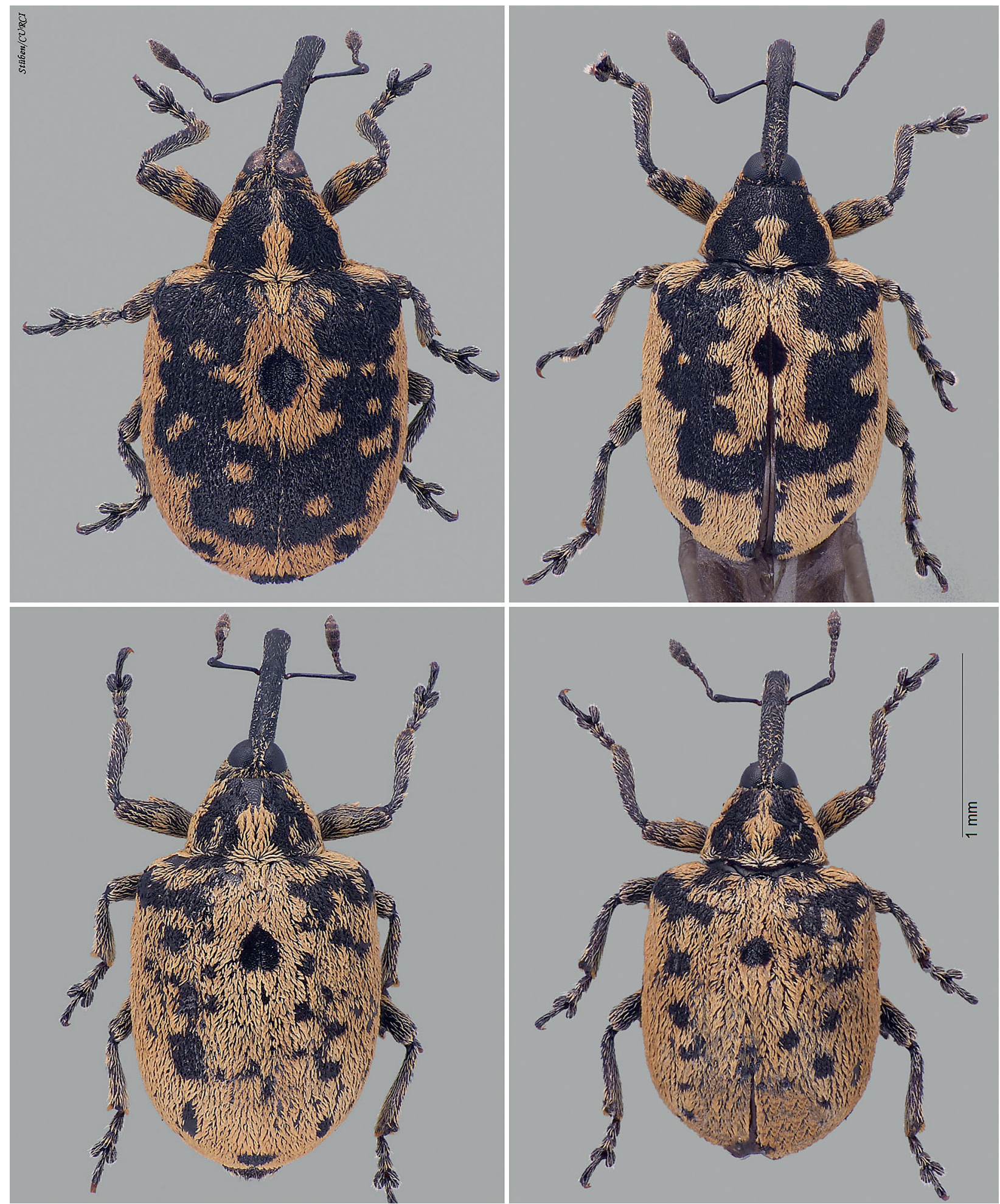

Fig. 3: The colour variants of Cionus griseus $\mathrm{x}$ variegatus in a single population on La Palma (Jedey). Is this a case of introgression after hybridization and, as a consequence, perhaps a new species?

drial tree (with p-distances of $5.3 \%$ ). Indeed, in a first morphological comparison, the specimens from the three westernmost islands show a broader rostrum in both sexes than the specimens from different sites in Gran Canaria (differences in the shape of the aedeagus can also be identified). The problem: Unfortunately, we do not yet have any knowledge of the type material of Lixus brevi- rostris BoHEMAN, 1835 (nor of its synonyms) from the south of Spain, in order to be able to make appropriate assignments if necessary. Therefore, in the near future the first author intends to carry out a corresponding revision of the Canarian Lixus brevirostris species complex with new descriptions of the extensive material already available to him. 


\section{Madeiracalles terminalis complex - at the beginning} of a very young species split?

What appears morphologically clear at first glance, is not always so from a molecular perspective. An example of this is the Madeiracalles terminalis complex from Madeira. M. terminalis tolpis is slightly smaller, the elytra are more slender, the rostrum in both sexes is longer and more curved, and the terminal setae of the aedeagus are shorter and finer than in the nominotypical taxon M. terminalis. The M.terminalis complex, which also includes the morphologically distinguishable species M. tristaensis, M. cinereus and new species soon to be described (in STÜBEN in press), contains molecularly difficult to distinguish species with often extremely low p-distance values $(<0.8 \%)$. However, the chronogram based on a phylogenetic analysis of the two mitochondrial genes $16 \mathrm{~S}$ and $\mathrm{CO} 1$ revealed that we are dealing with a very recent species split for Cryptorhynchinae, which, at just 0.85 million years, is similarly short to that of the laurisilva species around Silvacalles instabilis with 0.58 $1.04 \mathrm{Ma}$ (STÜBen \& Astrin 2010: Fig. 1B). Also in the latter species from the Canary Islands the morphological distinction is easy and hardly gives reason for false determinations.

\section{Rhinoncus - morphologically castor, molecularly bruchoides}

This case poses great puzzles for us. Even after multiple sequence analyses, the result was confirmed after collecting from two different sites on Madeira. The comparison with GenBank sequences also showed the same 'molecular picture': Rhinoncus bruchoides (HerBst 1784). Likewise, the morphological classification based on the reliable identification features and undoubted differential diagnoses (STÜBEN et al. 2012) as well as the verification by several experts resulted in a clear 'morphological picture': Rhinoncus castor (FABRIcIUS 1792). [The morphologically very similar species Rhinoncus bosnicus Schultze, 1900, which we were also able to sequence (2658-PSP|ZFMK), is out of the question here]. At this point, further speculations (e.g. transgression after hybridisation) are forbidden, as well as the suspicion that barcoding has reached its limits here. This case does not contain anything alarming or the search for quick explanations, but simply the request to resolve the contradiction through further research!

\section{Conclusion}

In view of the 468 of 735 Macaronesian weevils barcoded by us so far, only a few questions about so-called 'molecular species' that have so far eluded the morphological description ('overlooked species') must remain unanswered for the time being (for more comments see soon in STÜBEN, in press). In one species, namely the adelphotaxa Rhinoncus castor and R. bruchoides (Ceutorhynchinae), contradictions arose during (re)identification. Furthermore, the samples sequenced from many islands and intra-island locations confirm the expected morphological placement for nearly each species in the Bayesian $50 \%$ majority rule consensus tree (see electronic supplement, Fig. 2). As already Pentinsaari et al. (2014) conclude in their study on nearly 1900 Northern European Coleoptera, $\mathrm{CO} 1$ barcodes in particular not only lead to an almost certain re-identification of species and contribute to a remarkable differentiation of species, but also accelerate the discovery - in our case - of new weevil species on the Macaronesian islands. 150 years after the great discoveries of T.V. Wollaston, the hardly imaginable increase of new descriptions in the number of Entiminae and Cryptorhynchinae on all archipelagos of Macaronesia stands for this integrative taxonomic step in the last two decades (MACHADo et al. 2017, STÜBEN 2018c).

\section{Acknowledgements}

We thank Hannah Petersen (Zoologisches Forschungsmuseum Alexander Koenig, ZFMK) and Eva Kleibusch (Senckenberg, Deutsches Entomologisches Institut, SDEI) for the lab work and our Canarian colleagues, Antonio Machado and Pedro Oromí (Tenerife), for providing some mtCO1 sequences. We thank Peter Sprick (Germany, Hanover) for some critical comments and Jiri Krátký (Czech Rep. Hradec Králové), for the morphological verification of Rhinoncus castor from Madeira and the provision of $R$. castor and R. bruchoides from Slovakia and the Czech Republic for the sequence analysis.

\section{References}

Astrin, J. J. \& Stüвen, P. E. 2008: Phylogeny in cryptic weevils: molecules, morphology and new genera of western Palaearctic Cryptorhynchinae (Coleoptera: Curculionidae). - Invertebrate Systematics 22: 503-522.

Astrin, J. J.; Höfer, H.; Spelda, J.; Holstein, J.; Bayer, S.; Hendrich, L.; Huber, B. A.; KielhorN, K.-H.; $\quad$ Krammer, H.-J.; LemKe, M.; Monje, J. C.; Morinière, J.; Rulik, B.; PeterSen, M.; Janssen, H. \& Muster, C. 2016: Towards a DNA Barcode Reference Database for Spiders and Harvestmen of Germany. - PLoS ONE 11: e0162624.

Folmer, O.; Black, M.; Hoeh, W.; Lutz, R.; VrijenHOEK, R. 1994: DNA primers for amplification of mitochondrial cytochrome $c$ oxidase subunit I from diverse metazoan invertebrates. - Molecular Marine Biology and Biotechnology 3 (5): 294-299.

García, R.; Andújar, C.; Oromí, P.; Emerson, B. \& López, H. 2019: The discovery of Barretonus (Curculionidae: Cossoninae) in the Canary Islands: barcoding, morphology and description of new species. - Acta Entomologica 59 (2): 443-452. 
García, R. \& López, H. 2020: Ceutorhynchus castroi n. sp. de La Palma (Coleoptera, Curculionidae, Ceutorhynchinae). - Rev. Acad. Canar. Cienc., Vol. 31: 37-48 (XII.2019).

Hebert, P. D.; Cywinska, A.; BAll, S. L. \& deWaARD, J. R. 2003a: Biological identifications through DNA barcodes. - Proceedings of the Royal Society of London, Series B: Biological Sciences 270: 313-321.

Hebert, P. D.; Ratnasingham, S. \& deWaard, J. R. 2003b: Barcoding animal life: cytochrome c oxidase subunit 1 divergences among closely related species. Proceedings of the Royal Society of London, Series B: Biological Sciences, 270 Suppl. 1: 96-99.

Hundsdörfer, A.; Rheinheimer, J. \& Wink, M. 2009: Towards the phylogeny of the Curculionidea (Coleoptera): Reconstructions from mitochondrial and nuclear ribosomal DNA sequences. - Zoologischer Anzeiger 248: 9-31.

Kostal, M. \& Cladara, R. 2019: Revision of Palaearctic species of the genus Cionus Clairville (Coleoptera: Curculionidae: Cionini). - Zootaxa 4631 (1): 1-144.

KüNkeL, G. 1993: Die Kanarischen Inseln und ihre Pflanzenwelt, Stuttgart.

LisTA 2009: In this publication an abbreviation for: Oromí, P.; Cruz de la, S. \& BÁEz, M.: Coleoptera. In: Lista de especies silvestres de Canarias. Hongos, plantas y animales terrestres. 2009. AreCHAVALETA, M.; Rodriguez, S. M.; Zurita, N. \& GARCÍA, A. (Coord.): Gobierno de Canarias: p. 254-301.

Löbl, L. \& Smetana, A. (ed. 2011): Catalogue of Palaearctic Coleoptera. Vol. 7, Curculionoidea I, Stenstrup, Apollo Books: 373 pp.

Löbl, L. \& Smetana, A. (ed. 2013): Catalogue of Palaearctic Coleoptera. Vol. 8, Curculionoidea II, Leiden \& Boston, Brill: 700 pp.

Machado, A.; Rodríguez-Expósito, E.; López, M. \& Hernández, M. 2017: Phylogenetic analysis of the genus Laparocerus, with comments on colonisation and diversification in Macaronesia (Coleoptera, Curculionidae, Entiminae). - ZooKeys 651: 1-77.

Machado, A. \& Suárez, D. 2020: The genus Herpisticus Germar, 1823 from thje Canary Islands (Col.: Curculionidae: Entiminae: Tanymecini). - Graellsia, 76 (1): 1-92.

Marvaldi, A. E.; Oberprieler, R. G.; Lyal, C. H. C.; Bradbury, T. \& Anderson, R. S. 2006: Phylogeny of the Oxycoryninae sensu lato (Coleoptera: Belidae) and evolution of host-plant associations. - Invertebrate Systematics 20: 447-476.

Menier, J. J. 1974: Description d'une deuxième espèce du genre Aglycyderes Westwood: A. tavakiliani n. sp. (Col. Aglycyderidae). - Bulletin de la Société entomologique de France 79: 14-16.

Pentinsaari, M.; Hebert, P. D. N. \& Mutanen, M. 2014: Barcoding Beetles: A Regional Survey of 1872 Species Reveals High Identification Success and Unusually Deep Interspecific Divergences. - PLOS ONE 9 (9): 1-8.
Ronquist, F.; Teslenko, M.; VAN Der Mark, P.; Ayres, D. L.; Darling, A.; Höhna, S.; Larget, B.; Liu, L.; Suchard, M. A. \& Huelsenbeck, J. P. 2012: MRBAYES 3.2: Efficient Bayesian phylogenetic inference and model selection across a large model space. - Systematic Biology 61: 539-542.

StÜBen, P. E. \& Astrin, J. J. 2010: Molecular phylogeny in endemic weevils: revision of the genera of Macaronesian Cryptorhynchinae (Coleoptera, Curculionidae). - Zoological Journal of the Linnean Society 160: $40-87$.

Stüben, P. E. \& Behne, L. 2010: Hemitrichapion gomerense sp. n. (Coleoptera: Curculionoidea: Apionidae). - WEEVIL NEWS: - http://www.curci. de/Inhalt \& WEEVIL NEWS (printable version) 53 (12 July 2010): 3 pp., CURCULIO-Institute: Mönchengladbach. - PDF - (see: <http://www.curci. de/?beitrag=162>).

Stüben, P. E. 2011: Die Curculionoidea (Coleoptera) La Gomeras. - SNUDEBILLER: Studies on taxonomy, biology and ecology of Curculionoidea 12: (<http:// www.curci.de/?beitrag=177>), No. 177: 85-129.

Stüben, P. E.; Sprick, P.; MÜller, G.; Bayer, Ch.; Behne, L. \& KrátKÝ, J. 2012: Digital-WeevilDetermination for Curculionoidea of West Palaearctic: Transalpina: Ceutorhynchinae (1. Part). (Mononychini, Phytobiini, Hypurini, Cnemogonini, Scleropterini \& Amalini). - SNUDEBILLER: Studies on taxonomy, biology and ecology of Curculionoidea 13, No. 192: 18-33.

Stüben, P. E. \& Behne, L. 2013a: Die Curculionoidea (Coleoptera) Gran Canarias. Mit einem Nachtrag zu den Curculionoidea La Gomeras. - SNUDEBILLER: Studies on taxonomy, biology and ecology of Curculionoidea 14 (<http://www.curci.de/?beitrag=212>), No. 211: 53 pp.

StüBen, P. E. 2014: Die Curculionoidea (Coleoptera) Tenerifes. - SNUDEBILLER: Studies on taxonomy, biology and ecology of Curculionoidea $15<\mathrm{http}$ // www.curci.de/?beitrag=226>, No. 226: 118 pp.

Stüben, P. E.; Schütte, A.; Bayer, Ch. \& Astrin, J. J. 2015: The Molecular Weevil Identification Project (Coleoptera: Curculionoidea), Part II. Towards an Integrative Taxonomy. - SNUDEBILLER: Studies on taxonomy, biology and ecology of Curculionoidea 16, (<http://www.curci.de/?beitrag=237>), No. 237: $294 \mathrm{pp}$.

Stüben, P. E. \& Behne, L. 2015: Die Curculionoidea (Coleoptera) La Palmas. - SNUDEBILLER: Studies on taxonomy, biology and ecology of Curculionoidea 16 (242): 86 pp. - HTML - (see: <http://www.curci. de/?beitrag=242>).

Stüben, P. E. 2016a: The Macaronesian Islands - an Encyclopedia of Curculionoidea (Coleoptera). Le Charançon (Internet journal): Available at <http:// www.curci.de/institute3/catalogue_2/catalogue_2. php $>$ [viewed in January 2021]. 
StÜвEN, P. E. 2016b: Die Curculionoidea (Coleoptera) von Fuerteventura. - SNUDEBILLER: Studies on taxonomy, biology and ecology of Curculionoidea 17, No. 251: 38 pp., CURCULIO-Institute: Mönchengladbach (see: <http://www.curci.de/?beitrag=251>).

StüBen, P. E. 2017: Die Curculionoidea (Coleoptera) von den Inseln Madeiras und den Selvagens. SNUDEBILLER: Studies on taxonomy, biology and ecology of Curculionoidea 18, No. 261: $92 \mathrm{~S}$., CURCULIO-Institute: Mönchengladbach. - HTML -<http://www.curci.de/?beitrag=261>.

STÜBEN, P. E. 2018a: Die Curculionoidea (Coleoptera) von El Hierro. - SNUDEBILLER: Studies on taxonomy, biology and ecology of Curculionoidea 19, No. 269: 56 pp., CURCULIO-Institute: Mönchengladbach. HTML - http://www.curci.de/?beitrag=269.
Stüben, P. E. 2018b: Die Curculionoidea (Coleoptera) von Lanzarote. - SNUDEBILLER: Studies on taxonomy, biology and ecology of Curculionoidea 19, No. 271: 33 pp.

STÜBEN, P.E. 2018c: The Cryptorhynchinae of the Western Palearctic/DieCryptorhynchinae der Westpalaearktis, Curculio Institute: Mönchengladbach: 518 pp.

Stüben, P. E. \& Borges, P. A. V. 2019: Die Curculionoidea (Coleoptera) von den Inseln der Azoren. - SNUDEBILLER: Studies on taxonomy, biology and ecology of Curculionoidea 20, No. 279: 59 pp.

StÜBEN, P. E. (in press, 2022): Weevils of Macaronesia, Curculio Institute, Mönchengladbach, ca. 800 pp. 